7) F.T. Weiss, J.L. Jungnickel, E.D. Peters, Anal. Chem. 25, 277 (1953)

8) Ernst Ber1, U.S 2, 567, 468 Sep. 11 (1951)

9) M. Bushong, H.R. Cole, U.S. 2, 829, 115 Apr. (1958)

10) W.K. Lewis, A.B. Metzn, Ind. Eng. Chem. 46, 849 (1954)
11) J.G. Lillard, W.C. Jines, J.A. Anderson, Ibid., 44, 2623 (1952)

12) 吉村太, 工化 59，1050 (1956)

13) A S.T.M., D855-52T (1952)

14) M.R. Lipkin, I.W. Mills, C.C. Martin, W. T. Harvey, Anal. Chem. 21, 504 (1949)

\title{
Utilization of Acid Sludge
}

\author{
by Futoru Yoshimura \& Masamichi Maruoka
}

(University of Osaka Prefecture, Faculty of Engineering)

SYNOPSIS : - We have investigated carbonization of the acid sludge on the utilization of carbonization products and detergency of sulfonate separated from the acid sludge. When the acid sludge is heated slowly, $\mathrm{SO}_{2}$ evolves at about $90^{\circ} \mathrm{C}$, almost terminates up to about $350^{\circ} \mathrm{C}$, and the lower saturated hydrocarbon evolves extremely above $500^{\circ} \mathrm{C}$. The higher the carbonization temperature is, the more the sulfur content of carbonaceous material decreases.

The activities of carbon prepared from the acid sludge are satisfactory, when it is activated with steam for an hour, after heating at $850^{\circ} \mathrm{C}$ in the presence of sulfur.

From the comparison between surface tention, interfacial tention, penetrating, and foaming of Na-acid sludge sulfonate isolated from the acid sluuge and those of the commercial detergent, it will be considered the sulfonate is applicable as detergent, though its surface activities is lower than that of the commercial detergent.

\section{正 誤 表}

Vol. 40. No. 415, (1961)

日本コークス標準試料の標準值決定のための協同実験（石川, 他）

\begin{tabular}{|c|c|c|c|}
\hline & & 詥 & 正 \\
\hline 866 頁 & 左側下から 2 行目 & 参加分所析 & 参加分析所 \\
\hline " & 右側下から 2 行目 & 2 囲 & 2 回 \\
\hline 867 頁 & 第 0 表 試料 $\mathrm{A}$ & $\mathrm{V} \times 10$ & $\mathrm{~V} \times 10^{4}$ \\
\hline 868 頁 & 第 $2 \cdot 3$ 表 & JIS 許容量 & JIS 許容差 \\
\hline " & " 試料 A & 0.60 & 0.6 \\
\hline 869 真 & 右側上から 20 行目 & No. 12 のデーる & No. 12 のデータ \\
\hline "I & "I 21 行目 & 良好になタが & 良好になるが \\
\hline 871 頁 & 第 $5 \cdot 1$ 表 & アルカリ熔融法 & アルカリ融解法 \\
\hline 872 頁 & 第 $5 \cdot 3$ 表 許容差 & 所内 $\sigma_{2} \sigma_{w}$ & 所内 $\mathrm{D}_{2} \sigma_{w}$ \\
\hline "I & 下から12行目 & \pm 0.022 & \pm 0.028 \\
\hline 873 頁 & 第 6 表 備考 1 & B-1 $\cdots \sigma_{B}=0.0094$ & $\mathrm{~B}-1 \cdots \sigma_{B}=0.009$ \\
\hline 874 頁 & 左側下から 1 行目 & （信賴度 1-2） & （信賴度 $1-\alpha)$ \\
\hline
\end{tabular}

